\title{
醋酸ヴィニルと三鹽化エチレンとの共重合
}

岡村誠三・寒川治郎・松岡秀明

（1946年10月31临理）

著者は醋酸ヴィニル他のヴィニル化合物との共重合に就て研究しつ」あり本報告は其內の一部であ る。醋酸ヴィルとスチロール (岡村, 高分子化學, 1，50, 昭19), 醋酸ヴィニと姖水マレイン酸 (岡村, 池田, 同誌，1，58，昭19)及醋酸ヴィニルとアクリルニトリル(本號19頁)等に關しては既に報告した。醋酸

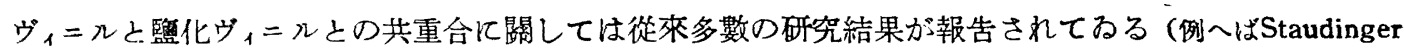
a. Schneiders, Ann., 541, 151, 1939; 櫻田・舟橋, 合繊分科會, 1942, 10 其他)。

著者等は監素を含有する醋酸ヴニル重合物を゙得る目的から三監化エチレンとの共重合に就て實驗 したので此處に其結果を報告する。三監佢ェチレンとの共重合に就てはあまり交獻はない。獨乙特許 550,883 (1928) 亿依る之醋酸ヴィニルと三及二監化エチレンとは嚴密な化學量論的な關係は無いが共重 合するものとして次の如き寅施例が揭げられてるる。郎ち醋酸ヴィニル $21 \mathrm{~kg}$, 三監化エチレン $14 \mathrm{~kg}$,

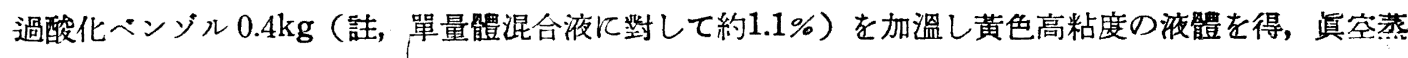
溜で未反應物を溜出除去すれば約 $120^{\circ} \mathrm{C}$ で熔融する固體 $28 \mathrm{~kg}$ （註，重合率 $80.0 \%$ ）を得ると言ふ。

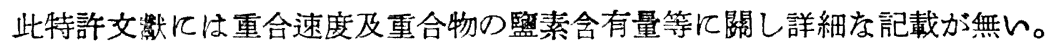

\section{1）驗 方 法}

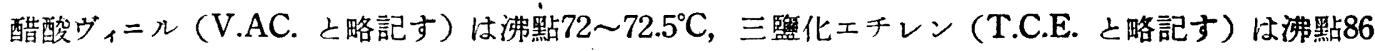
$\sim 86.5^{\circ} \mathrm{C}$ の溜分を使用した。重台方法としては過硫酸办里 $\left(\mathrm{K}_{2} \mathrm{~S}_{2} \mathrm{O}_{8}\right)$ を重合觸媒とする乳化重合法を 探用し，封管內に 單量體混合液之觸媒水溶液を入れ $60 \sim 70^{\circ} \mathrm{C}$ で緩徐に回轉 (16 r.p.m.) 振盪せしめ ながら重合せしめる。乳化重合後生成した乳濁液は食殈水溶液で監析し水洗水に監素イオンが認めら れなくなるまで充分水洗後風乾する。風乾物の一部沉就て含水率及監素含有率（過酸化》一ダ之硝酸 銀に依る常法）を測定し猶低重合物はベンゼン溶液に就て，此較的高重合物は二㿼化エチレン溶液之 して其粘度を測定した。

先づ V.AC. 亡 T.C.E. の混合液の比重及沸點を調べ第 1 圖の結果を得を。

第 1 圖に於て沸點は次の方法で定めた。郎ち V.AC. と T.C.E. との混合液を蒸溜フラスコに採り 加溫して蒸溜溫度と蒸溜時間を plotし蒸溜曲線が時間の軸に平行になる溫度を其混合液の沸點とした。 比重は內容 10c.c.のピクノメーターを使用した。第1圖に示した如く混合割合をモル\%で探ると沸點 も比重も何れもほよ゙直線的に變化し何等異常な變化は示さなん。T.C.E. 50モル\%(郎ち61重量\%) 以 下の混合單量體を取扱ふ場合には沸點は $79^{\circ} \mathrm{C}$ 以下であるから簡單を逆流冷却器を附したのみで常㻺 で重合溫度を $80^{\circ} \mathrm{C}$ まで帠せしめる事が可能である。猶比重の點から考へると T.C.E. 13モル\%（郎 ち18重量\%)の混合液は此重1.0であり水と共に㩭拌した場合に浮きもせず沈みるしない狀態にある。 
簡單に考へても此の㥞な狀態は乳化重合 を行ふ場合に望ましい狀態であらうと思 はれる。

\section{2）驗結 果}

先づ豫備實留として a) 逆流冷却器を 附し常壓で攬拌しながら乳化重合を行ひ， またb) 過酸化ベンジィル艾觸媒とし封管 內で塊狀重合を行ひ重合率とベンゾール 溶液 (C $=20 \mathrm{~g} / \mathrm{Lit}$.) の粘度 $\eta_{\mathrm{sp}} / \mathrm{C}$ を測定 乙第1表の結果近得た。

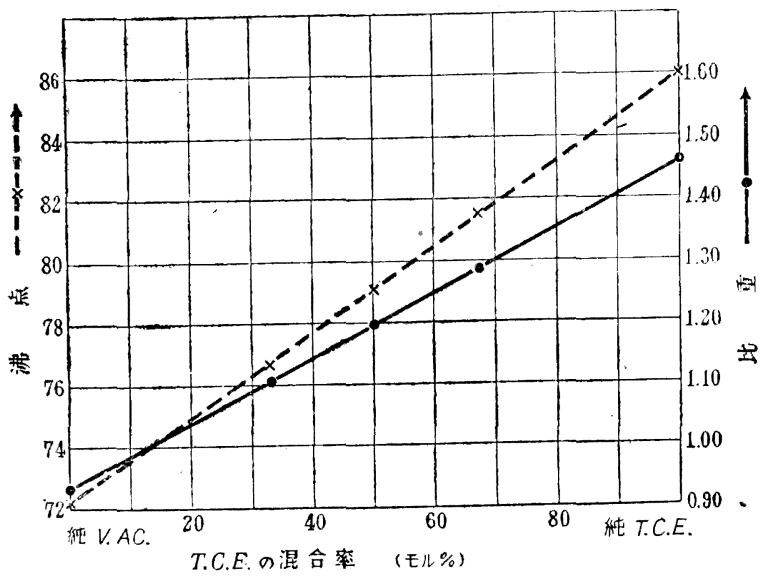

第 1 圆 V.AC. と T.C.E. の混合液の沸點と比重

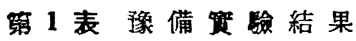

\begin{tabular}{|c|c|c|c|c|c|c|c|}
\hline No. & $\begin{array}{l}\text { T.C.E. } \\
モ ル \%\end{array}$ & $\begin{array}{c}\text { 電 合 觸媒 } \\
\left(\begin{array}{c}\text { 對混合液 } \\
\%\end{array}\right)\end{array}$ & $\begin{array}{c}\text { 重合溫度 } \\
\left({ }^{\circ} \mathrm{C}\right)\end{array}$ & $\begin{array}{c}\text { 重合時間 } \\
\text { (hr) }\end{array}$ & 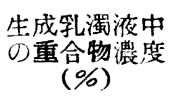 & $\begin{array}{c}\text { 重合 茶 } \\
(\%)\end{array}$ & $\eta_{\mathrm{sp}} / \mathrm{C}$ \\
\hline
\end{tabular}

a) 常愿筧挥乳化重合

\begin{tabular}{l|c|c|c|r|r|r|r}
\hline 1 & 50 & $\mathrm{~K}_{2} \mathrm{~S}_{2} \mathrm{O}_{8}$ & & & & & \\
2 & 33 & 1.0 & 80 & 6 & 6.36 & $59.2(39)$ & 0.004 \\
3 & 33 & 1.5 & 80 & 10 & 13.06 & $80.3(57)$ & 0.005 \\
4 & 13 & 0.5 & 75 & 10 & 2.20 & - & 0.006 \\
\hline \\
\hline
\end{tabular}

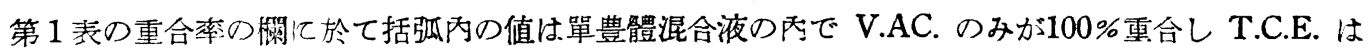
全然重合しないと考へた計算值である。此の樣にして得られる計算重合率よりも實測の重合率が何れ も大であり，また此の样な條件で V.AC. も100\% 重合するとは考へられなんから單量體混合物中の T.C.E.が重合に關與してるる事は明膫である。葍上表の重合物の溶液粘度は一般に極めて低く，また a)に於て僅かではあるが T.C.E. の混合割合が少ん程粘度が上昇する傾向にある。

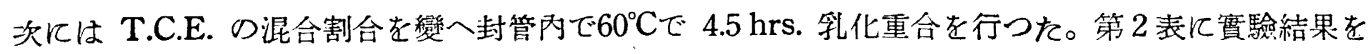
再錄する。

第 2 表の重合率筫測值からわかる如く T.C.E. の混合割合が增すに從つて全重合率は低下する。實 驗 No.8 亿示す如く此條件では V.AC.のみの重合に於て重合率は91.3\%に達する。今, T.C.E.が混 合された場合も假りに V.AC.のみは91.3\%が重合するよし，單量體混合物中の T.C.E.は全然重合し なんものとして重合率を計算し此の樣な計算值と實測重合率を比較して見ると實驗 9 11. 亿於ては大

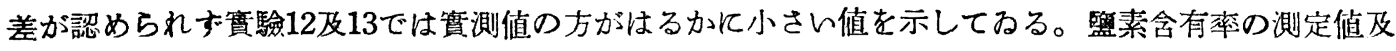


第 2 表 T.C.E. の混合割合に依る影箘

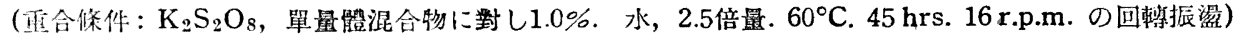

\begin{tabular}{|c|c|c|c|c|c|c|c|c|c|c|}
\hline \multirow{2}{*}{ No. } & \multicolumn{2}{|c|}{ 單量䯏混合物 } & \multicolumn{2}{|c|}{ T.C.E.混合割合 } & \multirow{2}{*}{$\begin{array}{c}\text { 央合物 } \\
\text { (g) }\end{array}$} & \multicolumn{2}{|c|}{ 重合㣞(） } & \multirow{2}{*}{$\begin{array}{c}\text { ベンゾール溶滩 } \\
\eta_{\mathrm{sp}} / \mathrm{C} \\
\mathrm{C}=20\end{array}$} & \multirow{2}{*}{$\begin{array}{l}\text { 緊素 } \\
\text { 含有伡 } \\
(\%)\end{array}$} & \multirow{2}{*}{$\begin{array}{l}\text { 重合物中 } \\
\text { の } \\
\text { T.C.E. } \\
\text { (モル\%) }\end{array}$} \\
\hline & $\begin{array}{l}\text { V.AC. } \\
(g)\end{array}$ & $\begin{array}{c}\text { T.C.E. } \\
\text { (g) }\end{array}$ & $\begin{array}{c}\text { 重 }(\%) \text { 量 } \\
(\%)\end{array}$ & $\begin{array}{l}E{ }^{\prime \prime} \\
(\%)^{\prime}\end{array}$ & & 實測 & 計算 & & & \\
\hline 8 & 2.004 & - & $\therefore 0$ & 0 & 1.824 & 91.3 & 91.3 & 0.077 & - & - \\
\hline 9 & 1.908 & 0.107 & 5 & 4.0 & 1.704 & 84.9 & 86.7 & 0.021 & 6.06 & 5.0 \\
\hline 10 & 1.689 & 0.307 & 15 & 10.9 & 1655 & 82.7 & 77.6 & 09 & 16.80 & 14.6 \\
\hline 11 & 1.392 & 0.608 & 30 & 22.5 & 1.213 & 60.0 & 63.8 & 0.004 & 31.95 & 30.5 \\
\hline 12 & 1092 & 0.926 & 45 & 35 & 0.553 & 27.4 & 50.2 & 0.003 & - & - \\
\hline 13 & 0.787 & 1.213 & 60 & 49 & 0.417 & 20.9 & 36.5 & 0.003 & 42.80 & 42.6 \\
\hline
\end{tabular}

重合物の溶解性から考へて此等の重合物が監素を含有してるる事は明瞭であるので T.C.E. が全然重 合に與つてるなんとは考へられなん。從つて單量體に T.C.E. が混合される事に依つて V.AC.の重 合率も低下するもの之推察される。特住重合物の監素含有率から算定した重合物中の T.C.E. の存在 モル\%の值を見ると，實驗9１1.に於ては單量體中の T.C.E. モル\%上り大きい值が見出されてるる。 此の事から V.A.C: の重合率が T.C.E. の重合率より小であらうと言ふ事が推定される。第2 表から 單量體混合液中の V.AC. と T.C.E. との混合割合, 重合物中の T.C.E. の存在割合及全重合率がか かるので次の計算に依り V.AC. 亡 T.C.E. の夫ね别ふの重合率が推算出來る。例へば筫驗 9 亿於て V.AC. の重合率を $\mathrm{x} \%$ T.C.E. の其れを $\mathrm{y} \%$ とれば,

$$
\begin{aligned}
& \frac{-4.0 \times y}{96.0 \times x+4.0 \times y}=\frac{5.0}{100} \\
& \frac{96.0 \times x \times 86+4.0 \times y \times 131.4}{96 \times 86+4.0 \times 131.4}=\frac{84.9}{100}
\end{aligned}
$$

(1)汲（2）式より

$$
\mathrm{x}=0.837 \quad \mathrm{y}=1.056
$$

即ち V.AC. は $83.7 \%$ 重合し, T.C.E. は105.6\%重合したと云ふ事になる。

\begin{tabular}{|c|c|c|c|c|c|}
\hline \multirow{2}{*}{ No. } & \multicolumn{2}{|c|}{ 單量體混合割合（モル） } & \multicolumn{2}{|c|}{ 單獨の重合染（\%) } & \multirow{2}{*}{ 全重合始(\%) } \\
\hline & V.AC. & T.C.E. & V.AC. & T.C.E. & \\
\hline 9 & 96.0 & 4.0 & 83.7 & (105.6) & 84.9 \\
\hline 10 & 89.1 & 10.9 & 76.0 & (118.7) & 82.7 \\
\hline 11 & 775 & 22.5 & 51.9 & 77.9 & 60.0 \\
\hline 13 & 51.0 & 49.0 & 22.6 & 17.4 & 20.9 \\
\hline
\end{tabular}
上の如を計算を實驗 $9,10,11$ 及13亿就て行ひ第 3 表の結果を得た。

第 3 表 各咸分の單獨の重合染

實驗 9 及10では T.C.E. 重合率が $100 \%$ 以上に出てみろが恐らく監素含有率の測定誤差之計算誤差 が加忙つて誤差が擴大されてるるるのと考へられる。從つて實驗 9 及10では T.C.E. は殆んど全部が 重合し V.AC. が85〜75\%重合してるる事となる。T.C.E. の割合が增加すると T.C.E. の重合率は急 激に減少し，また V.AC. の重合率も減少する事がかかる。此等の結果をベンジール溶液の粘度と共 


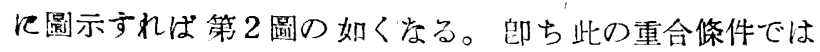
T.C.E. の混合割合が少い場合に床 V.AC.よりも:T.C.E. の方が重合率は大であり郎ち重合物中の監素含有率忙單量 體混合液中の其れより大である。㯰よりわかる如くT.C.E. 44 モル\%の單量體混合物を用ひ此條件で 重合せしめると V.AC. と T.C.E. とは泥合㓶合とほぶ同じ割合で重合し T.C.E. 44 モル\%装む重合物が得られるわけである。 T.C.E. が之より增すと T.C.E. の重合率が低下し重合物中 の監素含有率も小となる。ペンジール溶液の粘度はT.C.E. の混入量の堌加すると從つて急激に減少する。

次江 T.C.E. の混合割含〔一定として重合時間及水の量 の影響を見え。苗驗結果を第 3 表及第 4 表化示す。

第 3 裴でわかる如く重合の初期に 4 5 hr の誘導期が認 められる。溶液粘度は重合時間飞依つては大差は認められ 在的。

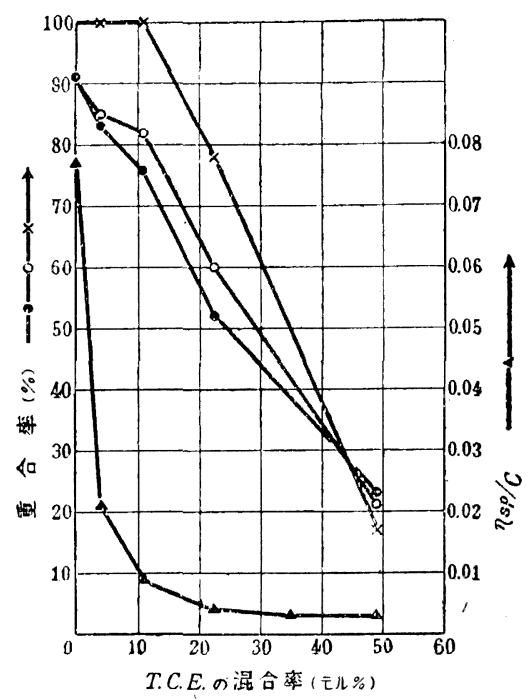

第 2 圆重合椡々粘度(第2表及第3表參炤)

- V.A.C.のみの重合锌

$\times$ T.C.E.のみの重合䇣 $\odot$ 全重合潐

第 3 表 重合時間に依万影製

T.C.E. 30 重量 $\%(22.5 モ ル \%), \mathrm{K}_{2} \mathrm{~S}_{2} \mathrm{O}_{8} 1.0 \%$ 混合物, $60^{\circ} \mathrm{C}$, 16 r.p.m.

\begin{tabular}{|c|c|c|c|c|c|c|}
\hline No. & $\begin{array}{l}\text { 重合晆間 } \\
(\mathrm{hr})\end{array}$ & 重 $\underset{(\mathrm{g})}{\text { 含 }}$ 物 & ${ }^{\text {重 }} \underset{(\%)}{\text { 拿 维 }}$ & $\begin{array}{c}\text { ベンゾール溶液 } \\
\eta_{\mathrm{sp}} / \mathrm{C} \\
\mathrm{C}=20\end{array}$ & $\begin{array}{c}\mathrm{Cl} \\
(\%)\end{array}$ & $\begin{array}{l}\text { T.C.E. } \\
(モ ル \%)\end{array}$ \\
\hline 14 & 4 & 篦析不能 & 0 & - & - & - \\
\hline 15 & 6 & 0.011 & 0.6 & - & - & - \\
\hline 16 & 10 & 0.293 & 14.7 & 0.003 & - & 一 \\
\hline 17 & 40 & 1.126 & 56.5 & 0005 & 32.86 & 31.5 \\
\hline . 11 & 45 & 1.213 & 600 & 0.004 & 31.95 & 30.5 \\
\hline
\end{tabular}

第 4 表水の量に依乃影繁

T.C.E 30重量\%， $\mathrm{K}_{2} \mathrm{~S}_{2} \mathrm{O}_{8} 1.0 \%$ 對單量體混合物， $60^{\circ} \mathrm{C}, 45$ hrs. 16 r.p.m.

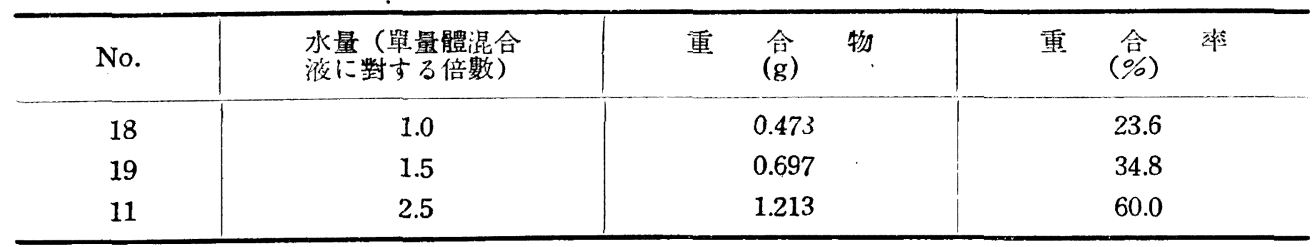

水の量は 1.0 2.5 倍の籁圍內では水量が多い程重合率は大である。

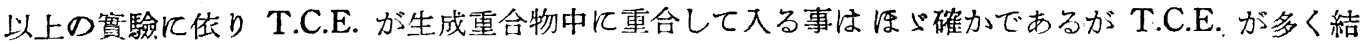
合すればする程ベンジール溶液の粘度が穎著に低下する。其處で次に相當程度の T.C.E. が結合し本

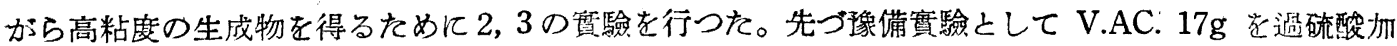
里 $0.1 \%$ 水溶液 150 c.c. と共に㨨䢁し乍ら $70^{\circ} \mathrm{C}$ 亿加熱し白濁し始めてから T.C.E. を $2 \mathrm{~g}$ 宛10分置をに 6 回計 $12 \mathrm{~g}$ 注入し 6 時間重合せしめた。其結果重合率約 $80 \%$ で重合物のベンジール溶液 $(\mathrm{C}=20)$ の粘 
度 0.012 之言ふ結果が得られた。郎ち第 1 表 No. 2 〜 之比較すれば T.C.E. を追加的に注加する事に 依り重合率はあまり變化せず重合物の溶液粘度がや」大となる傾向が認められる。其處で次には T.C. E.の添加方法を種々變化して筫驗し第 5 表の結果を得を。

第 5 表 T.C.E. 添加方法に依乃影亚, T.C.E. 20 重量\%(14.0モル\%)，水量，4倍. $70^{\circ} \mathrm{C}$. $\mathrm{K}_{2} \mathrm{~S}_{2} \mathrm{O}_{8} 1.0 \%$ (對混合物) 重合時間 $6 \mathrm{hrs}$.

\begin{tabular}{|c|c|c|c|c|c|c|c|c|}
\hline No. & 重 & 作 & $\begin{array}{l}\text { 重合率 } \\
(\%)\end{array}$ & 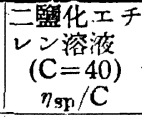 & $\begin{array}{l}\text { 臨素 } \\
(\%)\end{array}$ & $\mid \begin{array}{l}\text { T.C.E. } \\
(モ ル \%)\end{array}$ & $\begin{array}{l}\text { T.C.E. } \\
\text { 重合纱 } \\
(\%)\end{array}$ & $\begin{array}{l}\text { V.AC. } \\
\text { 重合漼 } \\
(\%)\end{array}$ \\
\hline 20 & \multirow{3}{*}{$\begin{array}{l}\text { T.C.E.添加速 } \\
\text { 度 } 0.25 \mathrm{~g} / 10 \text { 分 }\end{array}$} & $\begin{array}{c}\text { V.AC. 重合開始白溜後 } \\
\text { 直後よb }\end{array}$ & 85.3 & 0.049 & 12.28 & 10.6 & 64.7 & 90.5 \\
\hline 21 & & 30 分後より & 83.6 & 0.205 & 6.91 & 5.7 & 35.7 & 95.6 \\
\hline 22 & & 60分後より & 83.5 & 0.274 & 6.24 & 5.2 & 32.2 & S6.3 \\
\hline 23 & \multirow{3}{*}{$\begin{array}{l}\text { V.AC.重合開 } \\
\text { 始白濁後 } \\
\text { 直後よb添加 }\end{array}$} & $\begin{array}{l}\text { 添加速度 添加所要時間 } \\
1.25 \mathrm{~g} / 10 \text { 分 } 40 \text { 分 }\end{array}$ & 85.0 & 0.017 & 17.18 & 15.0 & 90.3 & 83.6 \\
\hline 24 & & $0.25 \mathrm{~g} / 10$ 分 3 時間 & 81.8 & 0.038 & 13.20 & 11.4 & 66.7 & 85.6 \\
\hline 25 & & $0.12 \mathrm{~g} / 10$ 分 6 時間 & 81.0 & 0.073 & 12.60 & 10.8 & 63.7 & 86.1 \\
\hline
\end{tabular}

此較赛驗 其 1. 觸 媒 濃 度

\begin{tabular}{|c|c|c|c|c|c|c|}
\hline No. & 合 & 件 & $\begin{array}{l}\text { 重合 率 } \\
(\%)\end{array}$ & $\begin{array}{c}\text { 二画化エチ } \\
\text { レン溶液 } \\
(\mathrm{C}=40) \\
\eta_{\mathbf{s p}} / \mathrm{C}\end{array}$ & ${ }^{\text {䈐 }}(\%)^{\text {素 }}$ & $\begin{array}{l}\text { T.C.E. } \\
(モ ル \%)\end{array}$ \\
\hline 26 & \multirow{3}{*}{$\begin{array}{l}\text { V.AC } \text { 重合開始白濁 } \\
\text { 後30分後よりT.C.E. } \\
0.25 \mathrm{~g} / 10 \text { 分て添加 }\end{array}$} & $\begin{array}{l}\text { 單量體混合物に對し } \\
\mathrm{K}_{2} \mathrm{~S}_{2} \mathrm{O}_{3} \quad 1.5 \% \\
\end{array}$ & - & 0.140 & 22.18 & 19.8 \\
\hline 27 & & $1.0 \%$ & 83.8 & 0.125 & - & - \\
\hline 28 & & $0.5 \%$ & 80.8 & 0.098 & 11.93 & 10.0 \\
\hline
\end{tabular}

比較赛驗 其 2. V.AC. 重合速度及溶液粘度 T.C.E, $0 \% \quad 70^{\circ} \mathrm{C}, \quad \mathrm{K}_{2} \mathrm{~S}_{2} \mathrm{O}_{3} \quad 1.0 \%$

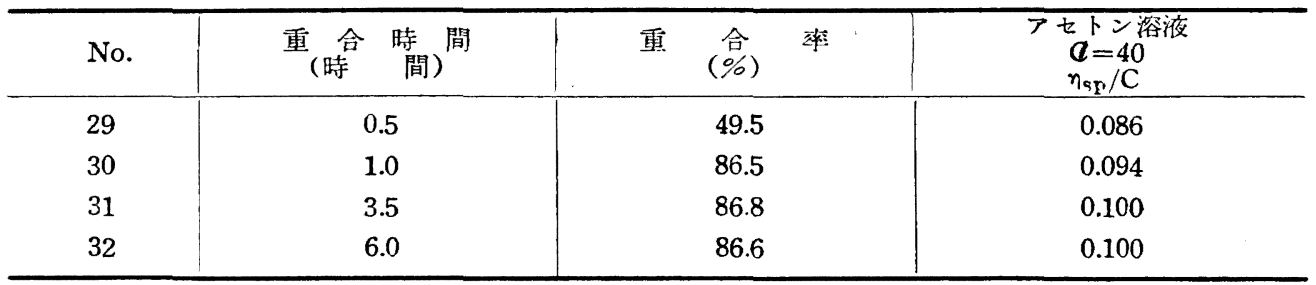

第 5 表沉於て T.C.E. の添加遊度を $0.25 \mathrm{~g} / 10$ 分と一定に保ち V.AC. 重合開始白濁直後より添加を 始めた場合と白濁後 30 分或は60分間はV.AC. のみ重合せし.めたる後に T.C.E. の添加を開始した場 合とを比較すると派加を幄く開始する程重合物の溶液粘度が高く監素含有率は小となつてるる。次に V.AC. 重合開始白濁直後より T.C.E.淁添加するとして添加速度を $1.25 \mathrm{~g} / 10$ 分, $0.25 \mathrm{~g} / 10$ 分, $0.12 \mathrm{~g} / 10$ 分 と變化せしめると添加速度が小さん程溶液粘度は高く監素含有率は小となつてるる。結局 T.C.E. の 添加は小さい速度で遲くから添加を始める程溶液粘度は高くなるが監素の結合量は減少するわけであ る。唒觸娫濃度は 1.5 乃至 $0.5 \%$ 範圍內では觸媒濃度が大なる程監素含有率も溶液粘度も大である事 が比較璝驗其 1 の結果から知られる。比較實驗其 2 からかかる如くV.AC. は 0.5h. で49.5\%，1.0h. で 86.5\%が重合する。從つて賽驗 No.20〜22 亿於て單量體 V.AC. 86モル（後に T.C.E. を14モル添加 
[137]

する) は T.C.E. 添加までに 0 (No.20) 42.5 (No.21) 74.3 (No.22)モルが重合し, 殘りの $86 \times \frac{90.5}{100}=$

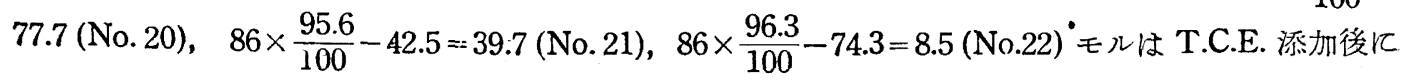

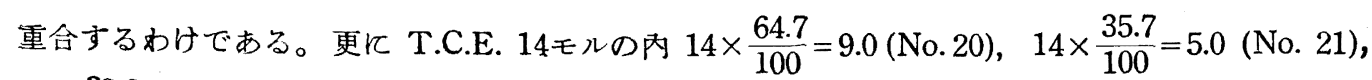
$14 \times \frac{32.2}{100}=4.5$ (No. 22) モルが重合するかけであつて, T.C.E. 添加に依つて T.C.E. 1 モルが重合す る間に V.AC. は 8.64 (No. 20), 7.94 (No.21), 1.89 (No. 22) モルだけ重合するわけである。郎ち同 一條件で重合せしめる埸合でも T.C.E. を添加する時の V.AC.の重合速度の大小に依り T.C.E. 之 V.AC. との結合する割合は變化する事がわかる。

猶 T.C.E. は生成重合物の溶劋であるので, 重合の最初から過剩の T.C.E. を共存せしめるち重合 能力ある一成分としてではなく過剩の T.C.E. は溶劑として作用し例入壮連鎻の停止反應を進めるた め重合度を低下せしめる。所が第 5 淁の䁈驗に於けるが如く重合するに從つて少量宛添加してやれば， 重合する成分としての T.C.E. のみが存在し溶劑の作用を營まないために溶液粘度の高い重合物が得 られたものよ推察される。

次に V.AC. 亡 T.C.E との共重合に依り得られを重合物の性質に就て考へて見る。先づ比較的低重 合度の重合物はベンジールに溶解するが垔合扊が少しく大になる之溶解せず二監化ェチレンにのみ可 溶性之なる。唒實驗 No.20乃至25或はNo.26乃至28で得られる重合物は何れるベンジールには不溶で あり二監化エチンンに溶解する。特にNo. 22の重合物が前述の如く全重量の $49.1 \%[=-(74.3 \times 89) /(82.8$ $\times 86+4.5 \times 131.4)]$ 郎ち約牛分が純 P.V.AC. であると考へられるにもかいからずベンゾール可溶部が 殆んど認められなん事は其原因江不明であるが注目される事柄である。

唒重合物の分離探取後は何れの場合にも室溫減壓で乾蝲し溫度を上昇せしめる事は極力さけた。若 し $105^{\circ} \mathrm{C} て ゙ 2 \mathrm{hr}$. 以上加熱して乾燥せしめると重合物は一部二監化エチレンにも不溶性となり該溶劑中

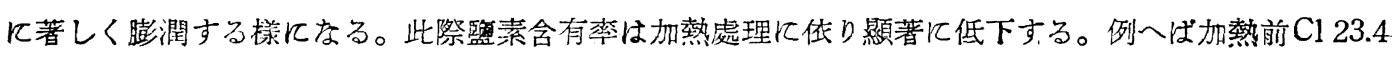

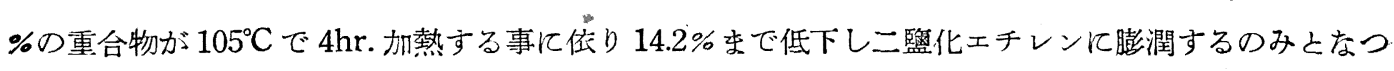
た。

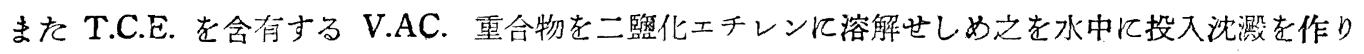
30 分間煮沸後取出して風乾する。此操作を繰返へすと最初の 1,2 回は監素会有率がや」低下するが二 轝化ェチレンへの溶解性は變化しなん（第 6 表)。

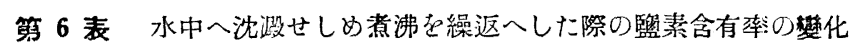

\begin{tabular}{|c|c|c|c|}
\hline 原 䑰 料 & $\mathrm{Cl}$ & $14.10 \%$ & 二監化エチレン可溶 \\
\hline 1 回處理 & & $13.85 \%$ & 可 溶 \\
\hline 2 回處理 & & $11 .: 8 \%$ & 可 溶 \\
\hline 3 回處理 & & $11.57 \%$ & 可 溶 \\
\hline
\end{tabular}

次に第 5 表 No. 21 及22の重合物を二監化エチレンに溶解せしめ硝子板上に流して減壓常溫で約牛月

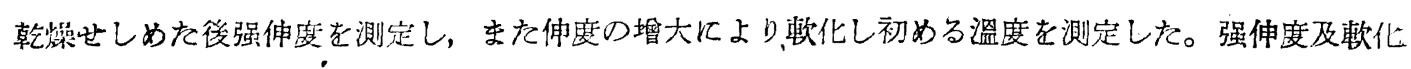
點の測定は辻和一郎助教授のもとで行はれたものであり此昝に感謝の意を表はす次第である。 
第 7 表 皮膜の 2,3 の性筫（辻助数授测管）

\begin{tabular}{|c|c|c|c|c|c|c|c|}
\hline 料 & $\begin{array}{l}\text { T.C.E.含 } \\
\text { 有 } € ル \%\end{array}$ & $\begin{array}{c}\text { 二監化エチンン } \\
(\mathrm{C}=40) \\
\eta: \mathrm{p} / \mathrm{C}\end{array}$ & $\begin{array}{l}\text { 皮膜原 き } \\
\left(\times 10^{-3} \mathrm{~mm}\right)\end{array}$ & $\begin{array}{l}\text { ヤング信: } \\
\mathrm{kg} / \mathrm{mm}^{2}\end{array}$ & $\begin{array}{l}\text { 强 } \frac{\text { 度 }}{\mathrm{kg} / \mathrm{mm}^{2}}\end{array}$ & 伸 $\%^{\text {度 }}$ & $\begin{array}{l}\text { 軟化點 } \\
\text { o }\end{array}$ \\
\hline リ酷酸ヴイニル & 0 & 0.323 & 2) & 39 & 2.05 & 25.7 & 35 \\
\hline No. 21 & 57 & 0.205 & 30 & 28 & 1.77 & 27.0 & $32-33$ \\
\hline INo. 22 & 5.2 & 0.274 & 61 & 12 & 138 & 164.9 & $<20$ \\
\hline
\end{tabular}

上表に方てNo.22は皮膜の厚さが厚く溶劑が殘存してるるためか伸度が大でヤング萑，强度及䎶化

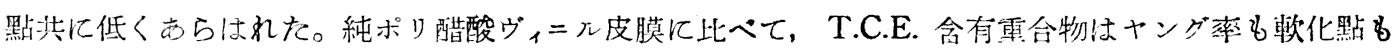
筧万低的值在示寸事がかかる。

\section{要旨}

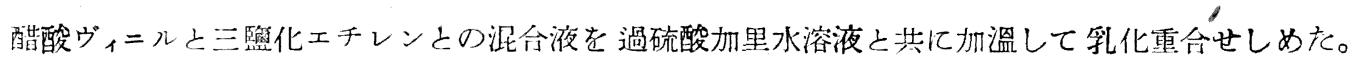
重合に依りボり醋酸ヴィニとは溶解性が異り，また明に監素を含有する共重合物が得られた。此際 三監化エチレン混合割合が堆すと共に全重合率及重合物の溶液粘度は低下し重合物り監素含有茶は上 昇する。醋酸ヴィニルのみで重合を開始し白濁が生じた後に三監化エチレンを徐々に滴下して行くと 重合物の監素含有量が大で且溶液粘度の此較的高い重合物が得られる。重合物は水之共飞煮沸すると 監素含有率がや」低下゙すが二監化エチレンの溶解性は變化しなん。'極ぐ街量の水の存在の下に高温

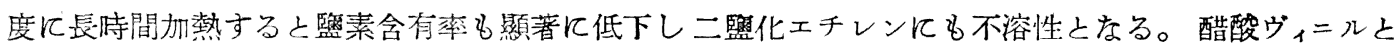
三監化エチレンの共重合物より作つた皮膜は純ポリ醋酸ヴィニル皮膜に比しヤング率, 强度及軟化溫 度共任低い值を示した。

終りに本转驗を行ふれ當り終始御鞭撻を賜つた榴田㸚授に厚く感謝の意を表する次第である。

\section{言分子友の會愈通 會㸃變更}

從來高分子太の會普通會員の愈費は一年分 10 圓とし，「高分子化學」を 配有致しておりましたが，最近の甚しい物價高により到底これでは助う ことができす, 且文高分子化學協會よりの補助金も僅少になりょしたの で，昭和 22 年1月度より1ケ年分30圈に改正致したいと存じます。よ.ろし く御諒承願います。

れ從來拂込の方は期限が來るまで舊會望で結楧です。

丈炤和22年1月1日以降排込办の方は新會費でお願いし末す。

特别會員は從前通り500圆 (終身筧费)です。

$$
\text { 「高分子唦”報」について }
$$

友の會より發行している、高分子抄報」につんては，各方面より頒布伴望の向があ りますが，用紙・印刷等の關倸上，友の會の特别會員以外几は配布しか玟ます。「抄 報」は現在第8號迄出ておりますが，主亡して海外のプラスティッス，合成纎維等に 關する紹介をしております。餘部が少しありますから，特別會員として新規御入會 の方には第 1 號より他の珰籍之一しよに御配布致します。 